\title{
ERRORS IN USING DICTION AND GRAMMAR OF STUDENTS' FINAL COURSE ACADEMIC WRITING OF DEPARTMENT OF ENGLISH EDUCATION AT JAKARTA STATE UNIUERSITY
}

\author{
Muhammad Jabal An Nur \\ Email: jabal@uin-alauddin.ac.id \\ Universitas Islam Negeri Alauddin Makassar
}

DOI: https://doi.org//0.24252/elties.vlil.7248

\begin{abstract}
This research aims to analyze in depth the use of diction error, subject and predicate, and the cause of the errors on students of English Education in State University of Jakarta. The research is a qualitative study using descriptive methods. The Instrument of this research is 50 students of third semester essay at the end of the task of writing an academic course of the academic year 2018/2019. The results of this research showed the majority of student errors occurred in the category of diction. Diction ranks first in the percentage of error as much as $63 \%$, followed by subject and verb agreement $37 \%$, and the cause of the error is due to the influence of the first language, translation, and carelessness.
\end{abstract}

Keywords: Diction, error analysis, grammar

\section{INTRODUCTION}

In language learning, especially foreign languages or second languages, It would be often encountered errors in the use of language being studied. By undesrtanding the location of the error then it will also be known which part in the language that needs to be improved.

Error analysis becomes one of the tools or media that can be used in analyzing second language learning. Error analysis becomes one of the linguistic studies that focus on the mistakes of students. Error analysis examines the comparison between errors made in learning a second language with the second grammar itself.

Error analysis is not a new thing in language learning, especially in learning a second language. Since it was first introduced in 1960 by Corder, the method is still used in various linguistic studies. In the past 50 years until now it must prove that this method provides great benefits and influence in language learning.

The benefits of error analysis are also expressed by some experts who increasingly point out the function and purpose of error analysis. According to Ellis (1984: 3). Error 
analysis is usually done with the purpose of revealing errors and finding the cause of errors or discrepancies and finding the right answer

Deepening the opinion of Ellis, Corder (1967: 167) as the inventor or father of error analysis argues that the mistakes made by the learner are important in which the errors can be determined which part of the learning process the student wants to strengthen.

Another opinion which states the usefulness of error analysis is presented by Candling (2001: 33) which assumes error analysis as "supervision and analysis of the language of the learner". He also added that the mistakes of second language learners are important to understanding their second language learning process.

Still with an opinion similar to previous opinion Feris (2005: 62) argues that correct error analysis and techniques can help in effective learning and teaching English as foreign language learning is a gradual process and during that stage mistakes will be possible at every level.

Another definition is also expressed by James (2013: 53) where, according to him, the analysis of error is a study of linguistic ignorance, an investigation of what one does not know and how they overcome their ignorance. This view emphasizes the function of error analysis which is used to help students find and then correct their own mistakes.

From some of these opinions may provide an illustration of how important error analysis in learning so it is not wrong if this analysis is still used to evaluate language learning, especially second language learning.

As a foreign language student who struggling in the field of academics, in course of completion of study requires a skill to write into a foreign language such as English.

Based on writer's research conducted independently that writing is something that has more complexity than other skills. This is because English that is studied more often spoken than written as a result of many students seems late to complete his studies due to weakness in writing skills.

Writing is a skill in which learners make a few sentences that are linked by certain rules and combine them in several ways but in writing or writing essays are likely to complicate the student.

Kern (2011: 42) explains that writing is an area where students make some mistakes but on the other hand, can help students in learning for the following reasons; Firstly, it reinforces the grammatical, idiomatic, and vocabulary that have been taught to the learner. Secondly, when students write, they have the opportunity to explore the language they 
learn including English. Thirdly, as they write, they will certainly be involved with the use of new languages, engaging in the expression of ideas, and the use of eye contact with their writing.

In writing, of course, also the attention of the diction and the second written grammar. Richards (2002: 157) in a lingustic dictionary says that diction is the word choice used by the author by determining which words are appropriate and effective for specific writing purposes.

In addition to diction, the use of appropriate grammar is also an important thing in the process of writing. According to Coghill and Stacy (2001: 151), grammar is a language is a set of rules that arrange parts of its structure. Grammar determines how words are arranged in the form of meaningful language units. One part of grammar is the subject and the verb. Quoted from the literature published by Troy University means that the subject in singular single form must be followed by a singular verb while the subject in the plural should follow the verb in the plural form as well.

However, in learning writing, it is undeniable that there is a huge possibility in making some mistakes which, in most cases, need to navigate the cause. Norrish (1983: 29) classifies the causes of error into three types: carelessness, first language disorder, and translation. The three types of causes of error can occur because the former is the result of carelessness. Carelessness is often closely related to lack of motivation. Many teachers will admit that it is not always the student's fault that he or she is losing interest, perhaps the material and/or presentation style is not suitable for him.

The second cause is the result of the first language disorder. Norrish states that learning a language (mother tongue or a foreign language) is a matter of habit formation. When someone tries to learn new habits that old will disturb the new one. This cause of this error is called the first language disorder

The last cause is a translation. Translation is one of the causes of error. This happens because students translate the first language sentence or idiomatic expression for the target language by word to word. This is probably the most common cause of errors and inappropriate word selection can also be a source of mishandling errors. Based on the above exposure, the researcher are interested to examine through the method of error analysis in writing skills. It is expected that the problem of writing English to students can then be evaluated through this research. 


\section{METHOD}

To be able to reveal the problems that exist in this research, the researcher used descriptive analysis method and error analysis. The method of descriptive analysis (Nanawi and Martini, 1996: 73) is used as a problem-solving procedure under study by describing the state of the object of research at the time of the study, based on the fact finding apparently as it is. Then the error analysis method is used as a method to analyze the data in this study because the method of error analysis is one attempt to identify errors (Pateda, 1989: 38).

The population in this study is the third-semester students of English academic year $2012 / 2013$ program, which consisted of 50 students. Determination of the population is based on the consideration that students who sit in the third semester already have a basic mastery of English grammar and vocabulary required as a prerequisite in producing English sentences. To strengthen the results of the research then the researchers took all students from the population. The data analyzed derived from the final assignment of students in the academic writing courses in the form of essays.

Afterwards, the collected data was analyzed by the steps as has been done by the wrong sentences from then wrong sentence is identified to know the type of error, for example; Errors of diction and misconduct of verbs and predicates, both categorized the type of error according to the category of error, the noticing the wrong sentence, and prove the mistakes that have been identified with the correct sentence, and in this data traced the cause of the error. The last is Summarizes the results of the analysis of the error data that has been identified.

\section{RESULTS AND ANALYSIS}

The results showed that there were errors in the predefined categories. From the results of the research as many as 164 errors in the category diction with error frequency as many as 103 errors or $63 \%$ of the total error followed by error subject and predicate agreement as much as 61 mistakes or $37 \%$ of total errors.

The dictionary language comes from the Latin diction which means expression. According to Fromkin (2007: 195), Diction is interpreted as a study used in describing the way in which a person pronounce a word, and in particular also concerning to the extent to which he speaks. The notion literally emphasizes the aspect of how the word is conveyed or it can also be said that the choice of word or Diction is the selection of words according 
to what we are about to express. In analyzing diction researchers using Oxford Dictionary advanced dictionary (OAD) to get the exact meaning of the selection of words on the student essay.

From the results of the following research are some examples of errors of diction and explanation of the location of the error and justification.

In the phrase "freshmen adopting to a new environment" and "freshmen adapting to a new environment" the error is on a misuse of the word adopting and adapting. In English the word adopt means adoption in the Indonesian language that literally means taking something for a certain need while the word adapt means adapting or adapting to something so in the context of the above sentence the word adapt is more appropriate. (OAD, 2012: 55).

The next sentence is ... "refused to except defeat" ... and "refused to accept defeat" ... in the word except which in Indonesian means except the word accept means accept so that if examined from the meaning of the above sentence should be chosen is the word accept. (OAD, 2012: 69)

The next analysis is on sentence ... around five hundred people.."and ... about five hundred people. The use of word around in English is not used to say approximately or about but the word used is about. (OAD, 2012: 46)

In the sentence "effected by the weather and" affected by the weather in English the word effected is a noun which means the result so it is not appropriate its use in the above sentence. Affected word is the right choice of words because it is a verb meaning to cause or is caused so that its use is more appropriate (OAD, 2012: 79).

In the sentence agree with your demands "and agree to your demands" The next word is "agree with means have the same opinion with someone so that its use is more in situation discussion or debating so less precise in the sentence above however, words agree to more precise in the above sentence because Meaningfully agree (OAD, 2012: 53).

The next error lies in the claim "appraised him of the situation" and apprised him of the situation ". The word appraised means evaluating it so that it does not have the appropriate meaning if it is inserted in the above sentence while the word apprised means telling it so it is more appropriate to use it. Both words are indeed almost have the same writing but must be careful in its use so it is not wrong meaning. (OAD, 2012: 54).

Next is the error of using diction in the words "argued with the plan" and "argued against the plan". The word argue with is used to express an opinion to a person while the 
word argued against is used to give an opinion about a person's opinion rather than an opinion given (OAD, 2012: 60).

Other diction errors are in the phrase "bare the weight of the panda on my back" and "bear the weight of the panda on my back". The word bare means release so that its use is not right in the sentence above. The word bear more precisely in the above sentence which means bind or bring so more precisely (OAD, 2012: 79).

Next is the phrase a bias and unfair test "and" a biased and unfair test. The above word bias is not appropriate for its use because it should use the adjective word biased because afterwards there is an adjective again if not so then the sentence becomes not matched (OAD, 2012: 86).

The next error is in the phrase "when I breath in the morning" and "when I breathe in the morning." "The word breath is a noun meaning breath so that it means to be ambiguous in the above sentence thus should the right word is the verb breathe Means breathing (OAD, 2012: 92).

The latest diction error is in the phrase "walk between the many statues" and "walk among the many statues". The use of the word between is not correct in the sentence above because the word is used to compare two things whereas to compare more than two things then it is used the word among.

\section{CONCLUSION}

From the results of the research and data analysis, it can be concluded that there are still plenty of errors made by the students based on the given criteria. Moreover, it can also be argued that the third-semester students of the English State University of Jakarta should deepen their study of the diction which is the first rank of error followed by the subject and the predicate. By knowing the location of the error and the cause then, of course, both students and teachers and related in the development with the development of materials so can minimize their shortcomings of errors.

\section{REFERENCES}

Corder, S. P. (1967).The significance of learners' errors. International Review of Applied Linguistics.

Candling, R. B. (2001). Vocabulary and Language Teaching. New York: Longman Inc, Ellis, R. (1994). The study of second language acquisition. Oxford: Oxford University. 
Ferris, D. (2005). Treatment of Error In Second Language Student Writing. Ann Arbor: University of Michigan Press.

Hadari Nawawi dan Martini Nawawi, (1995). Instrumen Penelitian Bidang Sosial, Yogyakarta: GadjahMada University Press.

Hornby, Albert Sydney, Michael Ashby, and Sally Wehmeier. (2000). Oxford Advanced Learner's Dictionary of Current English. Oxford: Oxford University Press.

Jack Richards,(2002)..Longman Dictionary Of Linguistics Third Edition.(London. Pearson Education Limited.

James, Carl. (2013). Errors in Language Learning and Use. Exploring Errors Analysis. Oxford: Oxford University Press.

Jeffrey Coghildan Stacy Magendanz. (2003). English Grammar. (New York: Wiley Publishing, Inc.

Kern, Richard, (2011). Literacy and language teaching. UK: Oxford University Press.

Pateda, Mansoer. (1989). Analisis kesalahan. Jakarta : Nusa Indah.

Norrish, John. (1983). Language learners and their errors. Macmillan.

Sridhar, Shikaripur N., and Kamal K. Sridhar. (1980)."The syntax and psycholinguistics of bilingual code mixing." Canadian Journal of Psychology/Revue canadienne de psychologie.

Victoria Fromkin; Robert Rodman; Nina M Hyams. (2007). An Introduction to Language Boston, MA : Thomson Wadsworth. 